\title{
Institutional Strategies and Effective Mechanism of Fisheries Self-governance in Korea
}

\author{
Sang-Go Lee \\ Dept. of Marine Business \& Economics, Pukyong National University, Busan 608-737, Korea
}

\begin{abstract}
In Korea, the role of $\mathrm{FC}$ (Fisheries Cooperatives) in self-governance is of significance for the sustainable development of fisheries. It should be understood from the view that the FC exists for fishing management of inshore and coastal fisheries. It is coastal fisheries consisting mostly of small-scale fishermen that need collaborations of small-scale fishermen in the fishing industry. One of the reasons why the fishermen association FC should have an important role in self-governance is that the spread of self-governance and new fishing and fishery management modes nationwide is the responsibility and role of FC as a deliverer of cooperative movements. Self-governance should be connected to economic projects of FC. As a self-governance is for increased income of fishermen, the scheme should be linked to resources management and raise added value of products, going beyond the establishment of biological resources management. Self-governance is a collaborative movement of fishermen, by which therefore, FC should play its part in the sustainable development of inshore and coastal fisheries. In nature, perfect fisheries self-governance is difficult, so certain government regulations such as limits on access will continue, once fisheries self-governance succeeds. However, the government should boldly reduce and transfer regulations other than the minimum management means, to expand fisheries self-governance. It is important to find cases of conflicts/disputes actively and conduct follow-up management of them in collaboration with local governments, FC, and councils of leaders. Even tasks of which excavation and coordination is completed should be checked for their implementation records on a regular basis and complemented or further adjusted, when necessary. Voluntary restructuring plans by type of inshore and coastal fisheries should be set up and upon request, assessed to promote voluntary participation in consideration of characteristics by business type for coastal fisheries restructuring, such as collaborative support with local governments.
\end{abstract}

Keywords Fisheries Self-Governance, Fisheries Cooperatives(FC), Fisheries Management Modes, Collaborative Movement, Small Scale Fishermen, Voluntary Restructuring Plans

\section{Introduction}

Fisheries self-governance is a fishing management regime to pave the way for a sustainable fishing environment via voluntary and responsible fishing management by fishermen within the context of existing relevant institutions and laws. Basically, fisheries self-governance is driven by voluntary management communities with the aims of increasing the income of fishermen and making fisheries sustainable. Since the regime was introduced for the first time in Korea, the number of participant communities has continued to increase to 758 in 2009 from 63 in 2001, with participant fishermen increasing from 5,000 in 2001 to 56,000 in 2009.[14]. This increase in number has resulted in qualitative improvements including better attitude of fishermen toward fishing management and the emergence of commu-

\footnotetext{
* Corresponding author:

sglee@pknu.ac.kr (Sang-Go Lee)

Published online at http://journal.sapub.org/ijaf

Copyright $(\underset{2011}{ }$ Scientific \& Academic Publishing. All Rights Reserved
}

nities that have enjoyed increased income. Besides fishing management policies, growing efforts have been made to achieve actual increase of income through fisheries self-governance[1,6].

Currently, fisheries self-governance evolves into the creation of fishing management regime through efforts by fishermen themselves. As voluntary fishing management aims to empower fishermen to raise their income and boost the economy of fishing villages by improving productivity, it can become an alternative for fishermen to overcome difficulties in and outside of the fishing industry. For this purpose, it is necessary among others for fishermen to identify problems of voluntary fishing management and make it more voluntary.

However, self-governance has its limits, as it has been initiated by the government on the basis of government subsidies as incentives. Now it should be led by the private sector-centered policy, and to this end, solidarity and strong leadership within the implementation community is most urgent of all. Efforts to maintain fishery orders via sustained management of resources, fishery habitat area management, 
business management, eradication of illegal fisheries, and settlement of fishing conflicts are urgent.

Since fisheries self-governance aims to increase income of fishermen and boost the economy of fishing villages by improving productivity through voluntary efforts on the part of fishermen, it can serve as an alternative to overcome difficulties in and outside of the fishing industry. For this, policies for fisheries self-governance should be transformed to a socio-economic fishing village movement, which is led by fishermen. Fisheries self-governance, or fishing management by fishermen, varies widely among regions, ranging from community-level management to collaborative management. In reality, however, things are not as simple as thought. First of all, active participation of fishermen as management party is needed. Collaboration among individual fishermen, management party, and local and central governments is a prerequisite to prevent fisheries self-governance from being another example of institutional failure[7].

Actions driven by interests of individual fishermen and collective pursuit of profits by management party are a serious threat to its success. Excessive interference and immature promotion by government only makes fishermen less voluntary, resulting in stronger institutionalized government interventions. Therefore, we heed to the criticism objectively that self-governance is simply a delegation of responsibility without sufficient preparations for it and the actual devolution of management functions.

Today, fishermen themselves admit problems of fisheries self-governance and make efforts for its development into a more voluntary socio-economic movement. As the government also hopes it to become a movement by fishermen, fisheries self-governance is more likely to be positioned as a new model of a fishing village movement for the future. In this respect, attention of fishermen and across the industry is required.

Ten years have passed since the introduction of fisheries self-governance. Over the recent years, extensive support from the government has made its dramatic development possible. Nevertheless, a specific review of the effect of relevant policies and problems with its directions for the future has yet to be made. To ensure its sustainable growth and development, it is important to assess the development of fisheries self-governance up to now, identify problems and challenges and thereby suggest directions for the future[12].

\section{Fisheries Self-governance Practices and Challenges}

\subsection{Practices and Effect of Fisheries Self-governance}

The number of communities participating in fisheries self-governance has increased over 9 times more in six years to 579 in 2007 from 63 in 2001 and to 758 in 2009, 12 times more in total, as presented in Table 1 . The number of participant fishermen also has raised about 12 times more to 56,000 in 2009 from 5,000 in 2001.

Table 1. Change in Participant Communities by Year and Type.

\begin{tabular}{|c|c|c|c|c|c|c|c|c|}
\hline & 2001 & 2003 & 2004 & $20 \prime 05$ & 2006 & 2007 & 2008 & 2009 \\
\hline Communities(No) & $\mathbf{6 3}$ & $\mathbf{1 2 2}$ & $\mathbf{1 7 4}$ & $\mathbf{3 0 8}$ & $\mathbf{4 4 5}$ & $\mathbf{5 7 9}$ & $\mathbf{6 5 9}$ & $\mathbf{7 5 8}$ \\
\hline $\begin{array}{c}\text { (Year-on-Year } \\
\text { Increase :\%) }\end{array}$ & - & $(54.4 \%)$ & $(42.6 \%)$ & $(77.0 \%)$ & $(44.5 \%$ & $(30.1 \%)$ & $(13.8 \%)$ & $\mathbf{( 1 5 . 0 \% )}$ \\
\hline $\begin{array}{c}\text { - Community } \\
\text { fishing }\end{array}$ & 32 & 61 & 92 & 159 & 233 & 294 & 341 & $\mathbf{3 9 1}$ \\
\hline - Sea farming & 11 & 15 & 22 & 46 & 70 & 72 & 78 & $\mathbf{8 0}$ \\
\hline - Capture fishery & 8 & 29 & 34 & 52 & 71 & 102 & 115 & $\mathbf{1 3 5}$ \\
\hline -Integrated fishery & 12 & 17 & 26 & 43 & 62 & 94 & 102 & $\mathbf{1 2 4}$ \\
\hline \begin{tabular}{c} 
- Inland fishing \\
\hline $\begin{array}{c}\text { Participant } \\
\text { fishermen }\end{array}$
\end{tabular} & $\mathbf{5 , 1 0 7}$ & $\mathbf{1 0 , 7 6 5}$ & $\mathbf{1 5 , 4 6 9}$ & $\mathbf{2 4 , 8 0 5}$ & $\mathbf{3 3 , 9 2 1}$ & $\mathbf{4 4 , 0 6 1}$ & $\mathbf{5 0 , 7 2 8}$ & $\mathbf{5 6 , 0 9 4}$ \\
\hline $\begin{array}{c}\text { (Year-on-Year } \\
\text { Increase :\%) }\end{array}$ & - & $(63.7 \%)$ & $(43.7 \%)$ & $(60.4 \%)$ & $(36.7 \%)$ & $(29.9 \%)$ & $(15.1 \%)$ & $(\mathbf{1 0 . 6} \%)$ \\
\hline $\begin{array}{c}\text { Average Number } \\
\text { of Members per } \\
\text { Community }\end{array}$ & 81.1 & 88.2 & 88.9 & 80.5 & 76.2 & 76.1 & 77.0 & $\mathbf{7 4 . 0}$ \\
\hline
\end{tabular}

Data source : [15] Seong-Min Park, 2010.

By type, comprehensive, capture and integrated fisheries communities with a greater effect of fisheries self-governance, in particular, have grown 2.5 to 3.3 times more than 2004, thanks to stronger incentives. Still, community fishing accounts for more than half, $51.6 \%$, followed by capture fishery, integrated fisheries, sea farming, and inland fishing in order, which raises the need for broader fisheries self-governance centered on capture fishery for the future.

Despite such a progressive increase in participants, increase rates have been declining since 2005 , and average number of members per community decreased to 74 in 2009 from its peak of 88.2 in 2004, which indicates that the communities are getting smaller[15].

Fisheries self-governance has an effect of improving attitudes of fishermen and establishing fishery orders. Such an effect or outcome is generally considered positive. It can contribute to the increased income of fishermen by managing fishing grounds and resources, and most participant fishermen view it as having a positive effect on increasing their income, which is possible by managing fishing grounds and resources. This shows that fishermen began to have favorable attitudes toward fisheries self-governance.

In this respect, its biggest outcome is this changing attitude of fishermen toward the management of fisheries resources. In fisheries self-governance, fishermen have been given more freedom regarding modes of resources management, making realistic management of resources possible and reasonable management of resources have led to increased income of fishermen and made subsidies available from the government. Consequently, the regime is a critical opportunity to help fishermen believe that its intro- 
duction serve their interests. In addition, a growing number of communities are known to benefit from participating in fisheries self-governance, which is one of the biggest changes.

Fisheries self-governance has contributed to the eradication of small fishing vessels known as a major cause for depletion of fishery resources and devastated fishing grounds by reckless harvesting and illegal fishing activities and to the gradual reduction of other illegal fishing practices. Established fishery order is a result of efforts to encourage those who commit illegal fisheries to give up their illegal fishing practices voluntarily, to settle disputes over fishing areas by internal arbitration, to create diversified sources of income fit to each region, and build resources by managing fishing grounds.[3]

Fisheries self-governance is not simply for the socio-economic profits of fishermen alone, but it is basically intended to solve fishery-related issues unable to address by existing fishing management. So, if the scheme is expanded to the entire fishing industry and fishing villages, local fishing orders will see a dramatic progress.

\subsection{Institutional Problems and Challenges of Fisheries Self-governance}

Fisheries self-governance of Korea started from the logic conflicting with fisheries that employees participate in management and work in accordance with rules set by them. While fisheries self-governance is automatically possible by voluntary rules in fishing grounds of fishing village, it is not easy to be implemented by fishermen in other permit-based coastal and offshore fisheries. Especially in the sense that there is no legal ground for fisheries self-governance, various institutional problems may be raised. Therefore, in the case of fisheries self-governance for permit-based fisheries under existing laws and regulations, if fishermen who are required to receive permits operate under the rules set by themselves, regardless of various permit-related rules and regulations, a number of problems could arise under the existing fishing management scheme. Rules to insure legal implementation of resources management and fishing management at the time of giving permits exist, and following these rules is to establishing fishery orders, and compliant fisheries are of fisheries self-governance.

Thus, this form of fisheries self-governance is possible if some degree of rights is granted in the form of exclusive ownership of fishing grounds or resources. Similar forms are fishing grounds of fishing village cooperatives, licensed fishing grounds for aquaculture, and self-governance of exclusive pre-occupation of location such as trap fisheries. Fishing village cooperatives are implementing fisheries self-governance by way of collaborative production, sale, and distribution of fishing grounds of member fishing villages under their voluntary agreements. Like this, voluntary management means a regime where fishing village cooperatives conduct production, sale, and distribution by concluding a voluntary management agreement specifying these activities, and fishing village fisheries community fishing of this kind can be a typical fisheries self-governance.

In this respect, fisheries self-governance in operation in Korea should be seen as a form of fishing management that can be confined to fishing grounds of villages, farms, and other exclusively preoccupied trap fisheries of fishing village cooperatives. Fisheries self-governance is soon to be expanded to cover coastal fisheries, but like fishing village cooperatives, it is doubtful for fisheries with a permit only to perform voluntary management, in the case of fisheries of migratory species or fisheries of multiple species with no fishing grounds. Therefore, fisheries self-governance regimes implemented by organizations or associations other than fishing village cooperatives have diverse legal and institutional problems that make it difficult to define it as a real fisheries self-governance.

In fisheries self-governance scheme, fishermen can maintain fishery orders successfully and conduct additional complementary management for their need to make fisheries sustainable, within the context of existing legal system for fishing management. Therefore, fisheries self-governance requires additional management efforts of fishermen within the context of existing legal and institutional fishing management framework. Fisheries self-governance cannot exceed the existing framework, and voluntary actions themselves, whether positive or illegitimate, may become illegal fishing activities, in worst cases. This is why a separate legal and institutional for the regime is not necessary, but fishermen should make efforts voluntarily within the context of the existing laws and regulations. Voluntary efforts by fishermen to sustain fisheries self-governance is the framework for the implementation of fisheries self-governance.[5], [6], [15]

In fisheries self-governance, fishermen conduct fishing management voluntarily within the context of the existing laws and regulations, without separate legal and institutional devices. Compliant fishing management is the very institutional one contrary to fisheries self-governance, and therefore, if identity is confused, and no systematic structure is devised because of the absence of legal and institutional instruments of fisheries self-governance, it is no longer fisheries self-governance.

There is no need for a new legal and institutional device other than current support from the government for fisheries self-governance, but fisheries self-governance only requires fishermen as leading player in the industry to fulfill their responsibility for fishing management voluntarily.

Participation in fisheries self-governance is motivated mainly by government incentives; incentives provided to communities by the government to foster them have helped active participation of fishermen. Although the incentives significantly helped promote participation of fishermen at first, they began to affect adversely expansion of participation among fishermen, as growing demands of fishermen for the relevant policy offset underlying purpose of fisheries self-governance - autonomy.

Basically, fisheries self-governance is a management 
scheme to establish fishery orders and make fisheries sustainable through voluntary effort of fishermen who abide faithfully by existing fishing management laws and voluntary management. Promotion and spread of such voluntary effort by the government can become an obstacle to voluntary efforts from the community of fishermen[11].

The community-based approach to fishing activities of fishermen is not always positive. History shows that fishing has been the history of overexploitation. Consequently, fisheries self-governance has also a tragedy of sharing due to the nature of self-governance communities. At this point where institutional safety device for the establishment of voluntary management is impossible, nothing can prevent the tragedy of sharing generated from self-governance communities. Especially because fisheries self-governance, in nature, is almost impossible within the context of legal and institutional framework the problem may become worse. As a matter of fact, the current institutional fishing management was introduced as a solution to the tragedy under fisheries self-governance of free fisheries.

Since fishermen assume fishing management responsibility under the fisheries self-governance, there are a variety of external influences; first of all, problems arising from contradictions of a state-led self-governance mechanism and the absence of voluntary post-harvesting management system, second, issues due to the expanded self-governance centered on the organization of communities, third, problems attributable to the conflict with an institutional fishing management scheme and its implementation and operation, and finally, deteriorated marketability of the industry led by fishermen producers.

\subsection{Problems of Implementation of Fisheries Self-governance}

The ultimate objective of fisheries self-governance lies in voluntary fishery resources management by fishermen, but it is unclear if fisheries self-governance is a policy simply for fishery resources management or embraces such goals as increase of income, improvement of fishing ground environment, and establishment of fishery orders. The current fisheries self-governance should be changed to increase income of fishermen. Still, the policy of income increase faces a tough challenge that it is a redundant policy.

Basically, fisheries self-governance aims to produce and sell jointly, and its communities are similar to cooperatives. In fisheries self-governance, fishermen, underprivileged socially and economically, are united to voice their rights through a collaborative economic system of joint production, sale, and profit distribution. It also has a free market aspect that encourages competition between communities and regions. Such a mixed nature is more prone to make these self-governance communities a cooperative and reflects one of the Korean traditional values - mutual aid.

\section{Guidelines for Fisheries}

\section{Self-Governance and the Role of the FC}

\subsection{Guidelines for Fisheries Self-governance}

The guidelines for fisheries self-governance should be developed considering the existing relevant laws and regulations, in accordance with which self-governance should be implemented.

Fisheries self-governance is implemented within the existing relevant fishing management framework. In community fishing, self-governance is implemented based on concept of fishing village cooperatives of fishing grounds and voluntary rules in a fishing village cooperative as a community. In some capture fisheries which are approved by the government, fishermen with a permit participate in and perform fishing management voluntarily in accordance with the basic requirements of the permit.

From the fact that fisheries self-governance is implemented under existing relevant fishing management framework, participation of fishermen is of great significance. Although fisheries self-governance is conceptually a scheme in which fishermen strive to solve various problems surrounding the fishing industry as well as fishing management on their own, participation is a prerequisite to make this possible. The easiest way to raise their participation is to manage fishing in a manner directly linked to their economic interests.

Secondly, it should be gradually expanded across the fishing industry, beginning with fisheries or communities easy to implement the scheme with quick effects. Fisheries self-governance is a movement based on the agreement of members of a community, rather than a policy or a program initiated by government. Therefore, to spread it quickly across the local fishing industry, the scheme should be implemented, beginning with fisheries or communities which have a favorable environment for its implementation and can generate a quick visible effect and be used as an example.

Thirdly, the role of fishermen in fishery resources management should be increased. Although the government defines its basic objectives, means, and directions, fishermen should participate in the process of setting up a concrete plan for target species, types of fisheries, and fishing grounds. For this, the establishment of self-governance fishermen associations should be easier and encouraged.

Fourthly, the government should empower fishermen to form diverse self-governance associations depending on the nature of fisheries, providing support for this. Rather than confining to existing fishing village communities under FC(Fisheries Cooperatives), and industry associations, creation of diverse homogeneous organizations should be promoted. In the meantime, the government should provide administrative, financial, and institutional support and put in place institutional improvement regarding the organization and operation of self-governance association to pave the way for self-governance in the industry. 
There are a set of necessary conditions for effective fisheries self-governance; first, fishermen as the real self-governance party should have the will of and capacity for its implementation and be homogeneous within self-governance communities in light of species, fishing technique, size of fishing vessels, and uniformity and soundness of businesses of social communities and the fishermen concerned.

Second, since complicated and unclear self-governance rules are hard to implement. They should be simple and clear for members to abide by, once come into forces after the organization launches.

Third, economic benefits, even if not in the short term, should be entailed from self-governance, so members can enjoy those benefits at least some time later.

Finally, even existing institutional fishing management led by the government should be transformed so as to encourage the participation of fishermen; that is, existing state-led fishing management should take bottom-up process, instead of top-down system $[5,13]$.

Given the need, concepts, and basic directions of fisheries self-governance, and condition for its implementation, directions for fisheries self-governance are as follows: First, fisheries self-governance should begin with licensed fisheries such as community fishing, which is easier to implement self-governance for and are more likely to succeed at early stages, expanding to coastal and offshore permit-based fisheries over time.

Second, fisheries self-governance should be implemented via collaboration among and between a local government responsible for licenses and permits regarding related fisheries, government authorities related to resources management, and fishermen communities, which mean those self-governance communities and the authorities, should have a horizontal relationship.

Third, a system should be formed to make and execute a plan to fulfill the resources management goal of the government and the maximized economic profit goal of fishermen, which should be developed ultimately into ITQ(individual transferable quota) fisheries self-governance under the TAC(total allowable quota).

Fourth, institutions in connection with self-governance of fisheries should be innovated. If a plan set up by an agreement between self-governance communities and the authority's conflicts with the current institution, strategies should be available to solve this problem by improving the institution.

Fifth, self-governance organization basically should be created on the basis of region and fishing gear and technique, and diverse organizations should be encouraged depending on fishing and regional characteristics. Therefore, bodies other than current region-based FC, fishing village communities, village or fishing gear/technique business types fisheries cooperatives by industry, and ship owner association are allowed as well.

Sixth, the government and self-governance communities should have their appropriate role. The government should set the basic direction for the fishery resources management policy, reorganize institutions for self-governance, give incentives, and provide administrative support. Self- governance communities should for an organization best representing target self-governance fisheries, implement the self-governance plan, put in practice voluntary oversight and supervision, and provide information about catches and others essential for resources management.

Finally, training of leaders who will be responsible for fisheries self-governance and education and promotion for fishermen should be continued, because fisheries self- governance is not a policy led by the government, but a scheme based on voluntary participation of fishermen, and therefore, the role of community leaders is important.

\subsection{The Role of FC for the Systematic Development of Fisheries Self-governance}

The role of FC(Fisheries Cooperatives) in self- governance is of significance for the sustainable development of fisheries self-governance for the future. It should be understood from the view that the FC exists for fishing management of coastal fisheries. It is coastal fisheries consisting mostly of small-scale fishermen that need collaborations of small-scale fishermen in the fishing industry. Management of them and fisheries explains why FC should operate for the future. Activation of fishing village communities and redefining of identity of FC is the key here. Fishing village cooperatives should be perceived as a sub-structure of FC or an incorporation (regional cooperatives) to create a win-win environment, and thereby, and self-governance and fishing village communities should be linked to promote tourism and create added values.

One of the reasons why the producer association FC should have a larger role in self-governance is that the spread of self-governance and new fishing and fishery management modes nationwide is the responsibility and role of FC as a deliverer of cooperative movements.

Second, self-governance should be connected to economic projects of FC. As self-governance is for increased income of fishermen, the scheme should be linked to resources management and raise added value of products, going beyond the establishment of biological resources management.

Third, self-governance is a collaborative movement of fishermen, by which therefore, FC should play its part in the sustainable development of inshore and coastal fisheries.[5]

As target resources of self-governance are fisheries resources as commons. fisheries self-governance organization should have the capacity to manage resources which are commons, characterized by impossibility of exclusion and competition. Consequently, the organization requires individual fishermen to manage fishery resources in fishing management, but fishermen as a rational economic player perform economic fishing activities for their own interests, that are intensive use or overexploitation of the resources, resulting necessarily in the failure of fishery resources management. To solve this problem, a state-led fishing 
management is implemented. However, this type of fishing management is accompanied by massive management costs including that for oversight of individual fishermen, which leads to national damage and inefficient fishing management regime.

Fishing management by $\mathrm{FC}$ ensures that management costs are minimized (increased national benefits) and fishery resources as commons are sustainable (reasonable management of resources) by establishing a system for coordination and monitoring of fishery resources as commons led by its members. This makes the management of fishery resources as commons by FC become a reasonable fishing management system that minimizes management costs and thereby maximizes fishing management. Therefore, FC should function as the user or manager of commons fishery resources in coastal and offshore waters, and it is considered appropriate to see FC as reasonable self-governance organization.

Fisheries self-governance aims to build a sustainable production environment of fisheries, settle disputes by region and type of fishery, increase and stabilize income of fishermen and contribute to the progress of fishing villages through fishermen and fishermen associations. Projects for this purpose include fishing grounds management, resources management, business management innovation, and maintenance of orders. The producer association FC may have a variety of roles in the self-governance process.

For this, internal incentives should be provided, and parties concerned should be motivated to participate in the process. In addition, education on the need of voluntary management should be carried out, and voluntary management should entail added value.

FC also should be responsible for resources necessary for fishing management jointly with the government and fishermen. This means that both parties should assume responsibility for self-governance projects equally, and NFFC should substitute resources of the government together with fishermen and their associations, as the government cannot provide all the funds and workforce necessary for fishing management. The government provides fishermen and their associations with information necessary for fishing management that is data on fishing grounds management, resources management, business management innovation, and maintenance of fishery orders and promotes the spread of self-governance.[14]

Since regional fisheries cooperatives aims to increase productivity of members, find markets, boost distribution, provide technology and information, and raise the economic, social, and cultural status of members. They can play a key role in terms of objectives of fisheries self-governance and promoted projects. Currently, in the self-governance process, FC play a very limited role such as hosting national conferences of fisheries self-governance and awarding excellent communities and contributors, holding symposiums and forums, electing executives, and organizing exhibitions and lectures. As a producer association, it does not engage directly, but play an assisting role.
The FC also should link self-governance to its cooperative movement as part of fishery and resources management and put in practice as a movement by member fishermen. The cooperative nature of fisheries self-governance should be reinforced, with self-governance being developed into a FC movement and self-governance communities are promoted as a smallest unit of its organization. This can strengthen the basic concept of self-governance that weighs solidarity and unity of communities as an organization, and give clear goals of managing fishery resources and increase income of fishing households, ultimately contributing to the social and economic development of fishing villages.

Via a redefined relationship with $\mathrm{FC}$, self-governance should be made a project guided by FC, which enables the collaboration between private self-governance organizations and FC. Also in regards to the status of self-governance communities, it is necessary to create a fishing village settlement having the nature of a community that has the status of existing fishing village communities at the same time. This can boost capture fisheries and help them grow to be broad-care communities by means of integrating regional communities. By reinforcing the cooperative nature of arbitrary organizations such as capture fisheries associations, going beyond boundaries of fishing village communities.

\section{Fisheries Self-governance Mechanism and Institutional Strategies}

\subsection{Strategies for the Institutionalization of Fisheries Self-governance Organization}

In general, self-governance organizations can be divided largely into two depending on industry and region. In general voluntary regulation, organizations by industry and business type are cooperative partners of government. It is natural because market regulation is made in terms of industrial structure. However, regulations of the fishing management may vary depending on the objective and target of management. If the objective is to manage a certain resource, business type specific organization is better, and regional organizations are more effective for the management of a certain fishing ground. Nevertheless, coastal fisheries in many cases are concentrated in narrow waters in diverse types and a single fisherman engages in multiple business types in most cases, making them hard to become a business type-based self-governance organization[11,13].

Traditionally, local fishing villages have been based on a social relationship based on blood ties and regionalism of people that share economic interests, that is, coastal fishing grounds. Accordingly, strong solidarity centered on natural villages and exclusive attitude towards outsiders have been formed naturally, which still remain as a favorable factor for the management of commons at a community level.

In Korea, regional communities called fishing village cooperatives based on this socio-cultural characteristic of fishing villages are in place widely alongside coasts na- 
tionwide, larger modern producer associations at the upper level called regional cooperatives control these fishing village cooperatives. The presence of such regional community organizations may serve as a basis for the formation of self-governance organization.

In this respect, it is more effective to have local communities implement self-governance of coasting fishing ground. Generally, local communities can select objectives, targets, and means of the management collectively. Also, they have advantages of relatively easy creation of the structure and control of members leading to maximized management effect and enabling a full consideration of regional characteristics of fisheries. It should be avoided, however, to standardize the type of self-governance organization and to confine to local communities. Various forms of fishing management organizations should be encouraged in consideration of situations and characteristics by region, fishing ground, and industry. Any producer associations or entities can become a self-governance organization only when they meet the basic personnel and material requirement.

Furthermore, self-governance organization should be expanded and organized by stage. At first, self-governance organization should be formed by village or fishing ground, creating a single community by unit in order to ensure reasonable scale and prevent overcrowd and unnecessary competition among communities. Internally, each community should organize its members by fishery type and their duty.

Next, regional communities should be expanded gradually to adjacent areas or waters. This broad-area expansion should be based on administrative districts or governing fishery cooperatives, fully considering region and conditions of fishing ground. Although coasting fishing grounds are divided by administrative district, fishing activities, in reality, are not limited, due to the nature of fishery resources. And management of limited waters alone cannot generate a better management effect. Therefore, individual bodies of coastal fishing management should be expanded to adjacent communities with higher interests over time and form a broad-area management system that integrates management by business type and water and enables joint management, information sharing, and coordination of interests.

However, they have following limitations as a self- governance organization of coastal fisheries:

First, to enable voluntary management of fishery resources all the members should accept the premise that "present individual profits should be regulated for the profits for all in the future." Among fishermen who use the same fishing ground for the same purpose, interests are highly homogeneous. However, fishing village cooperatives have fishermen of all business types in the area as members, it is hard to make their interests the same, and frequent conflicts of interests among members necessarily lead to lower concentration and will of management. NFFC plays their role in a number of economic projects and in wide range of areas. Its members are also diversified, so it is hard to ex- pect for NFFC to exert control and leadership necessary for the management of coastal fishing ground as a self-governance organization of coastal fisheries.[14].

Second, existing organizations have members exceeding a reasonable number. Just as small organizations are more effective for participatory democracy than larger ones, the number of members should be limited to a reasonable level, because more members may result in complex collaborative management in light of homogeneity of interests, difficulty of collective decision making and control, and greater internal conflict.

Third, fishing village cooperatives is considered to have a problem with the leadership and control of members. Specifically, fishing village cooperatives have been found to experience difficulty managing their fishing rights and to lease or distribute village fishing grounds and farms to individuals, or they directly managed them with lower productivity. Additionally, coastal fisheries are excluded from targets of management by fishing village cooperatives, leading to growing competition over fishing activities among members. Also, fishing village cooperatives have weak structures and financial bases in management functions, and their strong social ties become a barrier to management and control, making a strict implementation difficult.

Therefore, in the case of coastal fisheries, rather than using existing organizations, creating a new self-governance body should be encouraged if possible. Members of the new body should have strong economic dependency on coastal fisheries. In other words, they should devote themselves to coastal fisheries only or at least directly engage to increase their interests in coastal fishing management and organizational participation. This body also can have a proper set of conditions for a self-governance organization, as the number of their members become smaller than existing fishing village cooperatives.

In case where access to resources is open to the community only and controlled by compulsory rules, community organizations should have better access. Exclusive allocation of rights and limited access to commons results in a zero-sum game in terms of use rights. That is, exclusive rights to one group means exclusion of other groups, and when imbalance and loss arise the use of resource takes the form of privatization, not only 'tragedy of commons,' but also 'that of sharers' will appear. This is because the body that manages resources as a strong interest group attempts to exclude use rights of others and potential competitors. In this case, the use of resources may become less efficient, and fairness may be deteriorated to a large degree.

Thus, if there are public barriers to access such as permits, better access to the self-governance organization and lower membership fees are required to lower the barriers against access to new workforce and capital. Barriers to entry, if any, necessarily result in lower solidarity and management effect in the organization due to the presence of outsiders, likely leading to its collapse at last. Also in self-governance body of coastal fisheries, all fishermen involved should 
participate to maximize management effect.

\subsection{How to Make a Fisheries Self-governance Organiza- tion More Voluntary}

Self-governance organizations should have the freedom to choose objectives and devices of management in order to reflect characteristics of local fisheries, use their experience and information for management, and increase flexibility to changes. Therefore, self-governance organizations and rules common to all areas and fishing grounds should be avoided, and objectives and devices selected voluntarily by each organization should not be intervened if possible. In case where these rules are conflicted with other organizations with interests or violate public regulating instruments, a device should be available so as to coordinate differences by agreement.

Despite its realistic limit as permit-based fisheries, a self-governance body of coastal fisheries should have a certain control of its members and management targets. That is, it should be able to manage and control fishing grounds, resources, and members, along with the capacity of punishing violators of its rules. For this, a minimum of legal and institutional ground should be given to the body so that it can exert exclusion and control of target resources and fishing grounds. A proper coordination means should be in place to settle conflicts and divisions among and between members or organizations. Delegation of management responsibility does not mean the disappearance of fishery rules-related disputes and maintenance of their nature.

In nature, perfect fisheries self-governance is difficult, so certain government regulations such as limits on access will continue, once fisheries self-governance succeeds. However, the government should boldly reduce and transfer regulations other than the minimum management means, to expand fisheries self-governance. On the other hand, other means such as permit system should be made stricter(more strict), to control excessive catch-per-unit-effort and regain fishery orders by way of stricter crackdown and punishment of illegal and unfair fishing activities.

Meanwhile, these government interventions and controls should be different by fishermen attitude, fishing type, nature of fishing ground and resource, and socio-cultural conditions of the village. Since any self-governances are not possible for all areas and fishing grounds, nor self-governance is the only perfect form of fishing management, there is no need for the insistence on the scheme. Consequently, if conditions are not prepared, the government still should play a leading role.

Although diverse financial aids are needed to some degree to encourage and promote at early stages, the government should not engage directly in the creation of self-governance organizations, avoiding direct financial support if possible. Basically, self-governance organizations should be formed by the will of fishermen, while the government suggests a basic model, accredits the fishermen-led organization that meets a certain set of requirements as a self-governance organization and represents member fishermen.

In addition, supports for self-governance by the government should focus on technical aids. By reducing direct transfer spending such as awards or encouragement funds, strengthening environmental impact of resources of the fishing ground, providing education and technical aids, and building infrastructure, and provide information, indirect supports should be increased. Moreover, broad area self-governance organizations should be encouraged, with discrepancies of rules or disputes among these organizations being coordinated. With the help of active cooperation of fishermen, the government should enable collecting and measuring of information on fishermen, and reasonable measurement and management of resources.

\subsection{Effective Strategies for Fisheries Self-governance}

Self-governance should be established through environment-building and spread-development stages. As driving force of making a difference in fishing villages, participation of non-participating fishing village cooperatives nationwide should be encouraged, so that they can join the social change of fishing villages. Also, self-governance covering restructuring of coastal and offshore fisheries, management of TAC(total allowable catch) resources, and redevelopment of illegal farms should be boosted across the fishery policy.

With the aim of reinforcing continued education and promotion for fishermen and officials and thereby encouraging participation of non-participant communities, differential fostering funds by grade of communities should be provided to boost competition among communities. Training of leaders of excellent communities in fisheries advanced countries and award by the government should be made available. Areas where community fishing and capture fishery communities are present at the same time should be integrated as a complex fishery community. To this end, communities that operate community fishing only should remain community fishing communities, while capture fishery communities should become a broad-area organization, in consideration of regional characteristics and conditions of fishing grounds. One to two communities selected by sea water and type in consideration of conditions of fishing grounds and growth potential should be used for on-the-spot study and know-how transfers as a best model community. For better management of participant communities, stricter rules for resources management of the voluntary community agreement are essential, and therefore, regarding ban on catching, periods of ban on catching should be reinforced by the Order for the Protection of Fishery Resources[14].

It is important to find cases of conflicts/disputes actively and conduct follow-up management of them in collaboration with local governments, FC, and councils of leaders. Even tasks of which excavation and coordination is completed should be checked for their implementation records on a regular basis and complemented or further adjusted, 
when necessary. For a better arbitration of disputes, developments by task and on a quarterly basis should be reviewed, with selected tasks being promoted with the aim of completing within the year and with pending tasks being transferred to a fishery arbitration committee by sea area and continuously adjusted.

Voluntary restructuring plans by type of coastal and offshore fishery should be set up and upon request, assessed (business closure aids, etc.). To promote voluntary participation in consideration of characteristics by business type for coastal and offshore fishery restructuring, such as collaborative support with local governments. In case of associations based self-governance (closed season, mesh size, etc.), related fishery types and bodies should be empowered to voluntarily manage incentive-based TAC when allocating quotas. On the basis of producer association-local government or local government-central government agreements for sea weed and ear shell aquaculture, for example, voluntary redevelopment goals should be defined and achieved, delegating the redevelopment of illegal aquaculture farms to voluntary councils by item. Item-specific associations should be formed, and voluntary campaigns such as rallies to adopt a resolution to eradicate minerals and antibiotics, and other campaigns for dense planting to boost ecofriendly aquaculture.

\subsection{Growing Importance of FC for Fisheries Self-governance}

Despite slight differences of nature, self-governance communities are almost similar to communities of existing fishing village cooperatives. In coastal fisheries or village fishing grounds, communities of fishing village cooperatives played their roles to the full in solving many problems. When there are fishing village cooperatives as a basic form of fishing businesses, other fishery businesses as a community other than fishing village cooperatives are not necessary. The co-existence of fishing village cooperatives and self-governance communities is likely to lower efficiency of fishery business management, reduce the sense of belonging among fishermen, and internal conflicts due to unclear fishery business, and furthermore, is more likely to pose a threat to the solidarity among member fishermen and the development of fishing villages.

Organizing existing fishing village cooperatives as members of self-governance communities can be a solution to this problem. In addition, given that collaboration is important in fishing village cooperatives as a smallest structure of FC, a separate self-governance community is not necessary. Therefore, promoting self-governance based on the activation of fishing village cooperatives is more desirable within the existing fishing management framework.

Also to ensure a reasonable management of inshore fishery through regional branches of $\mathrm{FC}$, it is necessary to rationalize fishing village cooperatives. In relation with inshore fishery, if some fishing village communities or fishermen do not comply with rules applicable to all, trans- forming current mechanisms of fishing village cooperatives into those of regional branches of FC or incorporation of fishing village communities should be taken into account for a reasonable management.[15]

Considering not only a small-scale management centered on stationary species of inshore fishery, but also migratory species and coastal environment issues, medium- and large-scale management is needed. Of course, division of fishing grounds is a prerequisite for this. Furthermore, fishing village cooperatives under the control of regional branches of FC should be boosted so that they can contribute to the increased income and welfare benefits of fishermen.

\section{Conclusions}

Ten years have passed since the introduction of fisheries self-governance. Compared to 2001 when it was implemented for the first time in Korea, participant communities have increased more than 12 times, and its outcome includes continued organization of comprehensive communities and progressive participation of capture fishery communities. Although it is hard to say that such rapid increase in number has led to the qualitative development, steady supports from the government have helped push fisheries self-governance to the spread-development stage.

In reality, fisheries self-governance has helped restore fishery orders by rooting out illegal fisheries in coastal waters. Given the nature of fisheries, conflicts over fishing rights will never cease. Interwoven with their mutual interests, conflicts between coastal fisheries including community fishing and inshore fisheries in particular are becoming fiercer. This is a serious obstacle to the development of fisheries and the economy of fishing villages and requires an effective solution. Until now, due to the nature of fisheries that share the same fishing ground, conflicts and disputes arising out of the implementation of fisheries self-governance have been settled by voluntary discussion in the form of compromise and coordination between stakeholders arbitrated by private sector expert members of a voluntary arbitration committee.

There is no need to say that the creation of the fishing ground management party is the core of self-governance. Its personnel composition is the question now. Self-governance communities operate better if (a) they have a less number of members, (b) their members have stronger interest in the future, and (c) their interests are more homogeneous. Therefore, self-governance organizations should form a structure consisting of a reasonable number of individual fishermen that share the same management objective and target of reasonable use of fishing grounds, so that this structure can devise appropriate fishing management instruments and put them into practice. In Korea, bodies that are likely to serve as a managing party of fishing grounds of coastal fisheries include existing entities like FC, fishing 
village cooperatives, fishery management cooperative incorporation, as mentioned above

In Korea, the role of FC in self-governance is of significance for the sustainable development of fisheries selfgovernance. It should be understood from the view that the FC exists for fishing management of coastal fisheries. It is coastal fisheries consisting mostly of small-scale fishermen that need collaborations of small-scale fishermen in the fishing industry. One of the reasons why the producer association FC should have a larger role in self-governance is that the spread of self-governance and new fishing and fishery management modes nationwide is the responsibility and role of FC as a deliverer of cooperative movements. Self-governance should be connected to economic projects of FC. As self-governance is for increased income of fishermen, the scheme should be linked to resources management and raise added value of products, going beyond the establishment of biological resources management. Self-governance is a collaborative movement of fishermen, by which therefore, FC should play its part in the sustainable development of coastal and offshore fisheries.

In nature, perfect fisheries self-governance is difficult, so certain government regulations such as limits on access will continue, once fisheries self-governance succeeds. However, the government should boldly reduce and transfer regulations other than the minimum management means, to expand fisheries self-governance. It is important to find cases of conflicts/disputes actively and conduct follow-up management of them in collaboration with local governments, FC, and councils of leaders. Even tasks of which excavation and coordination is completed should be checked for their implementation records on a regular basis and complemented or further adjusted, when necessary. Voluntary restructuring plans by type of coastal and offshore fishery should be set up and upon request, assessed to promote voluntary participation in consideration of characteristics by business type for coastal and offshore fishery restructuring, such as collaborative support with local governments.

Self-governance seeks to maximize the effect of management of new governance, by encouraging voluntary participation of fishermen, instead of existing state-led management. It has been introduced as an alternative to overcome limits of the current management system such as overexploitation of fishery resources, worsening management of fisheries, and illegal fishing activities. As a driving force of making a difference in fishing villages, self-governance pursues to prevent illegal fishing activities, spread attitudes of resources management, and enhance the effect of management of fishery resources, and increase income of fishing households. Encouraging the entire fishing village cooperatives to participate in self-governance, the scheme should be established and become a broad-area body applicable to the fishery policy as a whole.

To ensure the successful established of self-governance in the fishing industry, the government should change their views on fishermen, the degree of public intervention, and government functions. The Korea government is reinforcing its policy to increase various administrative, financial, and technical supports for the early establishment of self-governance fisheries. Of course, given lacking will and experience of fishermen regarding fisheries self-governance, active supports and efforts may help a lot at first, but they finally serve to reinforce government intervention fishing management and become bureaucratic, distorting initial objectives. Related to fisheries self-governance, the role of $\mathrm{FC}$ as a producer association will become important in the future. Above all, its regional branches are expected to be of significance in coastal fishing management. Therefore, FC should realize that it exists for coastal fishing management. For this, fishing village cooperatives as sub-units of regional branches of FC should be activated, by which the win-win environment for self-governance is built.

\section{REFERENCES}

[1] Jae-Song Choi·Lee Myung Seok·Bae In Myung, (2001) Voluntary Solution of Commons Issues: focusing on Fisheries Self-Governance of Janggodo Island, Boryung, Chungnam. Study on Korea Public Administration, Vol. 10, No. 2, pp. 152-172

[2] Jong-Hwa Kim, (2009) A Study on the Institutional Improvement and Directions of Fisheries Self-Governance of Korea, Graduate School of Gangwon National University Press

[3] Jun-Seok Gang, (2002) Policy Directions for Fisheries Self-Governance", Modern Marine, Vol. 404, pp. 41-43

[4] Gwang-Nam Lee, (2005) A Study on the Strategies for the Activation and Participation in Fisheries Self-Governance in Capture Fisheries. Report No. 433. Ministry Of Maritime Affairs \& Fisheries

[5] Korea Fisheries Association(KFA), (2009) A Study on the Successful Establishment of Fisheries Self-Governance. Report No. 23. Institute of the Fisheries Policy of Korea Fisheries Association

[6] Sang-Go Lee, (1996) A Basic Study on the Resources Management System to Meet the International Marine Order in the 21st Century and Responsibility and the Environmentally Friendly Fisheries Policy. Fisheries Economic Study, Vol. 3, No. 1, pp. 59-92

[7] Sang-Go Lee and Ryu Jeong Gon, (2001) A Study on the Cooperative QMS under the Korean TAC System", Collection of Theses of Fisheries Business Management. The Fisheries Business Administration Society of Korea, Vol. 32, No. 1, pp. 99-123

[8] Sang-Go Lee and Ryu Jeong Gon, (2002) A Study on the Theoretical Background and Implementation Directions of Fisheries Self-Governance. Fisheries Study, Vol. 19, No. 1, pp. 33-49

[9] Sang-Go Lee and Shin Yong Min, (2004) A Study on the Development of Self-Governance Model of Coastal Fisheries of Korea. Collection of Theses of Fisheries Business Management, Vol. 35, No. 1, pp. 87-115 
[10] Seong-Ae Choi, (2002) A Case Study on Fishing Management fishermen through the Participation of Fishermen. Monthly Marine and Fisheries, Issue 217, pp. 58-69

[11] Seong-Ae Choi and Han Gyu Seol, (2002) A Study on Voluntary Management Organization of Coastal Fishing Grounds, Report No. 102. Korea Maritime Institute

[12] Shin Yong Min, (2003) A Study on the Industrial Structure Policy for Fishing Management By Market Incentives. Collection of Theses of Fisheries Business Management, Vol. 34, No. 2, pp. 1-26
[13] Su-Hyun Kim, (2002) A Study on the Establishment of Self-Governance of Coastal Fishery: focusing on the case of using village fishing ground on Chujado Island, MBA Master's Thesis, Pukyong National University Press

[14] Yong-Hun Choi, et al., (2008) Fisheries Self-Governance and the Role of NFFC, Report No. 45. National Federation of Fisheries Cooperatives, Fisheries Economic Institute

[15] Seong-Min Park, (2010) A Study on the Present Situations and Directions of Fisheries Self-Governance of Korea. Pukyong National University Press 